\title{
Enhancement of the attractiveness of mice as mosquito bait by injection of methionine and its metabolites ${ }^{1)}$
}

By

Toshiaki Ikeshoji2)

In addition to carbon dioxide, amino acids have been well studied by an olfactometer in relation to their attraction for mosquito biting. The author (1963) also determined the attractiveness of various amino acids and their decomposed products for Culex pipiens pallens by applying an aqueous solution to mice, and found methionine and several others to be highly effective.

In vivo experiments, on the other hand, which have been rarely conducted so far, are expected to reveal other aspects of the dynamic status of the chemical constituents in blood which attract mosquitos.

In the present work, methionine and its probable metabolic compounds which arise along the metabolic pathways were intraperitoneally injected into mice, and enhancement of the attractiveness was demonstrated. In order to supplement the results, mouse blocd to which had been added these active compounds was tested also by an olfactometer.

The author wishes to express his gratitude to Mr. Ikuo Motoyama, Department of Biochemical Cell Research, the Institute for Infectious Diseases, for operation of the automatic amino acid analyzer.

\section{Methods AND MATERIALS}

Mosquitoes: Culex pipiens fatigans collected from Okinawa and bred in the laboratory for several years were used at 4 and 5 days after emergence.

Mice: Mice available commercially varying

1) This work was supported by WHO Medical Research Grant No. R/00122, and in part by Public Health Service research grant No. CC 00168-01, from the Communicable Disease Centre, Atlanta, Georgia.

2) 池庄司敏明：Department of Parasitology (Chief : Dr. M. Sasa), the Institute for Infectious Diseases, the University of Tokyo, Shiba Shirogane, Minatoku, Tokyo from 12 to $16 \mathrm{~g}$. body weight were employed. Both sexes were used indiscriminately but were of similar size for a single test. The usual nutritionally balanced food pellets for breeding laboratory animals were given throughout the experiments rather than a defined diet.

One tenth $\mathrm{ml}$. aliquots of various chemical solutions were injected intraperitoneally. Six to 9 repetitions were made for each test on each chemical, each concentration, and each time after a treatment when attractiveness was expected; otherwise, only 3 to 6 repetitions were made. For in vivo tests, blood was drawn from the hearts of several mice by a syringe, and fresh blood serum was prepared by permitting it to stand in a refrigerator for 8 to 10 hours.

Chemicals: Amino acids used were all Lform, unless stated otherwise, and chromatographycally pure. Other chemicals were of either special or first grade.

In viro experiments: Individual mice were fixed in a small bag of wire gauze and confined in a trap made from a glass pot, $12 \mathrm{~cm}$ long and $9 \mathrm{~cm}$ wide, covered with a net cone at the top. The trap was then covered with a sheet of black paper. Two traps, one containing a treated and one a non-treated mouse were set in a mosquito cage, $40 \mathrm{~cm}^{3}$ in the evening. On the next morning female mosquitces trapped, regardless whether fed or not, were counted.

In vitro experiments: The same type of olfactometer designed by Gouch and Schreok (1965) was used for the in vitro tests: the mosquito chamber consisted of a transparent. plastic box, $40 \mathrm{~cm} \times 40 \mathrm{~cm} \times 80 \mathrm{~cm}$ in length equipped with two cylindrical traps, $5 \mathrm{~cm}$ wide and $20 \mathrm{~cm}$ long, at one end and an air-outlet at the other. A 10 watt electric heater used for warming water for tropical fish was encapsuled in a thimble, on to which either $1 \mathrm{ml}$. 
of the blood serum or the same volume of water as a control was absorbed for a test. By connecting two heaters in parallel, the thimble radiates heat at mouse body temperature at the surface. In the evening, approximately 6 hours after releasing 200 female mosquitos into the chamber, electricity was turned on to warm the heaters and ventilate the air. By means of a time-switch the electric supply was cut off after 5 hours, and the mosquitos trapped were counted next morning.

Analysis of free amino acids in blood serum and skin of mice: By addition of trichloroacetic acid blood serum of about $9 \mathrm{ml}$, but in precise volume, from several mice was deproteinized, and dried slowly in an autoclave at a temperature of $75^{\circ} \mathrm{C}$. The residue was dissolved in a buffer solution described later. Skin was peeled off from 3 mice as thin and cleanly as possible, and $6.4 \mathrm{~g}$. in wet weight was extracted with water by a soxhlet appara- tus for 2 hours. By addition of $\mathrm{CCl}_{3} \mathrm{COOH}$ and followed by filteration, the extract, somewhat colored, was dried as above. The samples of free amino acids were analyzed by using a KLA-2 type, Hitachi automatic amino-acid analyzer; the basic amino acids were on a 15 cm column of Amberlite CG-120 type III, 400600 mesh, with a buffer of $\mathrm{pH} 5.28,0.35 \mathrm{~N}$ Na-citrate at $50^{\circ} \mathrm{C}$; and the neutral amino acids were on a $150 \mathrm{~cm}$ column with buffers of $\mathrm{pHs}$ 3.25 and $4.25,0.2 \mathrm{~N}$ Na-citrate.

\section{RESULTS}

In vivo experiments : The maximum attractive effect of methionine was shown in 1.5 days (between 32 and 40 hours) after injection of $0.5 \%$ or 3.4 micromoles, of methionine, which was 5 times the amount inpregnated on the body surface of a mouse in the previous experiments (Table 1 and Ikeshoji, 1963). The

Table 1. Attractiveness ratios of the treated mice against the untreated for biting of Culex pipiens fatigans

\begin{tabular}{|c|c|c|c|c|c|c|}
\hline \multirow{2}{*}{ Compounds injected } & \multirow{2}{*}{\multicolumn{2}{|c|}{ Concentration \& Dose }} & \multicolumn{4}{|c|}{ Days after injection } \\
\hline & & & 0.5 & 1.5 & 2.5 & 3.5 \\
\hline Methionine & $0.5 \%$ & $3.4 \mu \mathrm{mole}$ & 0.95 & $3.47^{*}$ & 1.92 & 2.02 \\
\hline Methionine & 2.5 & 16.8 & & 0.61 & 1.64 & 0.22 \\
\hline $\begin{array}{l}\text { Methionine }+ \\
\text { DL-Ethionine }\end{array}$ & $\begin{array}{l}0.5 \\
0.5\end{array}$ & $\begin{array}{l}3.4 \\
3.1\end{array}$ & & 0.61 & 0.51 & \\
\hline $\begin{array}{l}\text { Methionine + } \\
\text { Cystine }\end{array}$ & $\begin{array}{l}0.5 \\
0.05\end{array}$ & $\begin{array}{l}3.4 \\
0.2\end{array}$ & 1.11 & 1.31 & 0.62 & \\
\hline $\begin{array}{l}\text { Methionine + } \\
\text { Cysteine }\end{array}$ & $\begin{array}{l}0.25 \\
0.25\end{array}$ & $\begin{array}{l}1.7 \\
2.0\end{array}$ & 1.72 & 1.17 & 2.23 & \\
\hline Cysteine & 0.05 & 0.4 & $2.40^{* *}$ & 0.52 & 0.77 & \\
\hline Cysteine & 0.5 & 4.1 & 0.26 & 0.55 & 0.26 & \\
\hline Cysteine & 0.05 & 0.2 & 0.87 & 1.76 & & \\
\hline Choline chloride & 0.1 & 0.8 & 1.10 & 1.58 & & \\
\hline Choline chloride & 0.5 & 4.1 & 0.95 & 1.64 & 0.51 & \\
\hline Creatine & 0.05 & 0.3 & 0.95 & 0.91 & & \\
\hline Creatine & 0.5 & 3.4 & 1.27 & 0.79 & & \\
\hline Glycine & 0.05 & 0.7 & $4.68^{*}$ & 1.58 & 0.85 & \\
\hline Glycine & 0.5 & 6.7 & 1.06 & 0.75 & 0.60 & \\
\hline Taurine & 0.05 & 0.4 & 1.66 & 1.36 & 0.43 & \\
\hline Urea & 0.05 & 0.8 & 0.16 & 0.51 & & \\
\hline Urea & 0.5 & 8.0 & 0.34 & 2.01 & & \\
\hline Pyruvic acid & 0.05 & 0.6 & $2.52^{*}$ & 1.04 & & \\
\hline Pyruvic acid & 0.5 & 5.7 & 0.81 & 2.18 & & \\
\hline
\end{tabular}

* These are significantly different from the control at the $95 \%$ level.

:** This is significantly different only at the $90 \%$ level. 
attractiveness ratio of the treated mouse against the untreated, i. e. 3.47 , was significantly different from 0.95 in 0.5 day after the treatment, which latter value was considered as the control test in the present study. The attractiveness ratios afterwards, 1.92 in 2.5 days and 2.02 in 3.5 days were higher than the value in 0.5 day, although the differences were not significant at the $95 \%$ level of probability. Methionine at the concentration of $2.5 \%$ was not attractive on any day tested. The attractiveness of methionine was, however, completely cancelled by addition of DL-ethionine, an antimetabolite of methionine. Methionine mixed with either cystine or cysteine at the concentrations tested was not attractive. Cysteine alone at $0.05 \%$ in 0.5 day after injection was attractive at the $90 \%$ level of probability. Cysteine at $0.5 \%$ and cystine at $0.05 \%$ were, however, not attractive.

When the probable intermediate products, glycine and choline, were tested, the former was highly attractive at $0.05 \%$ in 0.5 day, having the attractiveness ratio of 4.68. Pyruvic acid, a metabolite of cysteine and hence of methionine, was also significantly attractive, having the ratio 2.52 in 0.5 day upon injection of $0.05 \%$ solution.

Creatine, a probable metabolic end product of methionine, was not attractive at concentrations of $0.05 \%$ and $0.5 \%$.

Taurine and urea which showed a substantial increase in the blood serum of the treated mice by the chemical analysis mentioned later, were only slightly attractive, the former in 0.5 day and the latter in 1.5 days after treatment.

In vitro experiments: Additional effects on the untreated mouse blood of the chemicals, which were either proved to exist in the blood of the attractive mouse after injection of methionine, or to enhance the attractiveness of the mouse upon injection, were determined also by an olfactometer. The results are given in Table 2. The attractiveness ratios of the compounds compared to the same volume of water were all higher than the untreated mouse-blood, although these ratios were not significantly different due to the large standard deviations among the replications.

Change of the content of free amino acids and the related compounds in the blood serum and skin of mice after the treatment with methionine: The results of chemical analysis for amino acid content in the blood serum and skin of mice after intraperitoneal injection of 3.4 micromoles of methionine are shown in Table 3. Taurine, one of the intermediate matabolic products of methionine, and urea increased significantly in the blood serum of the treated mice, the former became 2.5 times on the 1st day after treatment and the latter became 7 times on the 2 nd day, and the peaks of these compounds coincided with the enhanced attractiveness of the treated mice. A relative increase of intact methionine, although negligibly small when compared with the injected dose of 3.4 micromoles, was shown in the blood serum as well as in the skin. A minute, but definite increase of methionine sulfoxide was observed between unkown compound 3 and aspartic acid in Figure 1. The other related amino acids, i. e., cysteic acid and cystine decreased in the blood serum to some extent. Substantial increases of aspartic acid and glutamic acid were shown in the blood serum and the skin. Proline, on the other hand, decreased in content by half on the 1st day after treatment and further undetectable amounts on the

Table 2. Attractiveness ratios of the mouse-blood added various chemicals against the same volume of water in an olfactometer

\begin{tabular}{|c|c|c|c|c|c|}
\hline \multirow{2}{*}{ Chemicals added } & \multirow{2}{*}{$\begin{array}{l}\text { Dose in } \\
\text { micromoles }\end{array}$} & \multirow{2}{*}{ No. of replicates } & \multicolumn{3}{|c|}{ Attractiveness } \\
\hline & & & $\%$ & S. D. & Ratios to water \\
\hline Methionine & 3.4 & 7 & 74.1 & 9.3 & $2.86^{*}$ \\
\hline Urea + Taurine & $8.0,0.4$ & 6 & 69.0 & 9.1 & 2.22 \\
\hline Choline chloride & 4.1 & 6 & 71.2 & 9.2 & 2.47 \\
\hline Glycine & 0.7 & 7 & 68.0 & 8.9 & 2.12 \\
\hline None & & 8 & 59.9 & 8.3 & 1.49 \\
\hline
\end{tabular}

* None of these figures on this column are significantly different from the control blood. 
Table 3. Contents of free amino acids in blood serum and skin of mice after intraperitoneal injection of $0.1 \mathrm{ml}$ of $0.5 \%$ methionine

\begin{tabular}{|c|c|c|c|c|c|c|}
\hline \multirow{3}{*}{ Amino acids } & \multicolumn{4}{|c|}{ A. A. in micro $\mathrm{mole} / \mathrm{ml}$ of blood serum } & \multirow{2}{*}{\multicolumn{2}{|c|}{$\begin{array}{l}\text { A. A. in micro mole/ } \\
\text { g. of skin }\end{array}$}} \\
\hline & \multicolumn{3}{|c|}{ Days after injection } & \multirow{2}{*}{ Control } & & \\
\hline & 1 & 2 & 3 & & 1 day after & Control \\
\hline Lysine & 0.025 & 0.022 & 0.032 & 0.021 & 0.919 & 1.025 \\
\hline Histidine & -- & - & - & -- & 0.161 & 0.143 \\
\hline Arginine & - & - & - & - & 0.454 & 0.488 \\
\hline Taurine* & 0.061 & 0.050 & 0.037 & 0.025 & & \\
\hline Urea* & 0.071 & 0.099 & 0.032 & 0.014 & & \\
\hline Cysteic acid & 0.018 & 0.021 & 0.025 & 0.025 & 1.264 & 1.219 \\
\hline Aspartic acid & 0.048 & 0.033 & 0.053 & 0.035 & 3.270 & 2.379 \\
\hline Threonine & 0.015 & 0.021 & 0.029 & 0.012 & 0.371 & 0.386 \\
\hline Serine & 0.047 & 0.033 & 0.042 & 0.024 & 1.957 & 1.921 \\
\hline Glutamic acid & 0.070 & 0.068 & 0.063 & 0.053 & 1.192 & 1.074 \\
\hline Proline & 0.026 & - & 0.062 & 0.053 & 1.103 & 1.178 \\
\hline Glycine & 0.053 & 0.070 & 0.089 & 0.068 & 2.925 & 2.873 \\
\hline Alanine & 0.114 & 0.149 & 0.252 & 0.162 & 2.374 & 2.584 \\
\hline Cystine & - & - & - & 0.052 & 0.123 & 0.111 \\
\hline Valine & 0.047 & 0.042 & 0.058 & 0.033 & 0.896 & 0.924 \\
\hline Methionine & 0.003 & 0.003 & 0.002 & 0.002 & 0.154 & 0.148 \\
\hline Isoleucine & 0.024 & 0.015 & 0.027 & 0.011 & 0.396 & 0.421 \\
\hline Leucine & 0.037 & 0.046 & 0.046 & 0.025 & 0.799 & 0.797 \\
\hline Tyrosine & 0.008 & 0.011 & 0.018 & 0.012 & 0.470 & 0.523 \\
\hline Phenylalanine & 0.008 & 0.006 & 0.009 & 0.007 & 0.456 & 0.523 \\
\hline
\end{tabular}

* These are expressed in the term of methionine.

2nd day in the blood serum and to some extent, in the skin. Between cysteic acid and aspartic acid shown on the chromatograms of Figure 1, there were three peaks of unidentified compounds which were also presumed to be metabolic derivatives of the methionine injected.

Although the substantial decrease of these compounds nicely coincides with the increase in taurine and urea contents, and with enhancement of the attractiveness, the significance of these compounds is not known.

\section{Discussion}

Some metabolic pathways of methionine in vivo are presented in Figure 2 and enhancement of the attractiveness of mice after injection of methionine is discussed in accordance with the pathways.

The effect of intact methionine: Since methionine, per se, was not attractive when determined in aqueous solution by an olfactometer, and only a slight increase of methionine content was observed in the blood serum of treated mice in spite of the significant enhancement of attractiveness in 1.5 days after treatment of 3.4 micromoles of methionine, this compound, intact, is not likely to be responsible for the enhanced effect. As further evidence of this, cancellation of the enhanced effect was demonstrated by simultaneous injection of ethionine which causes a deficiency of hepatic adenosine phosphate by accumulation of $\mathrm{S}$ adenosyl ethionine, and hence inhibition of hepatic protein synthesis, transmethylation from methionine to choline precursors, and so on (Smith and Salmon, 1965, and Farber, et al., 1964). Addition of 3.4 micromoles of methionine, the equivalent dose which presented maximum attractiveness on injection, to $1 \mathrm{ml}$. of fresh blood serum did not give a significant enhancement of the attractiveness when tested by an olfactometer, although the ratio of 2.86 


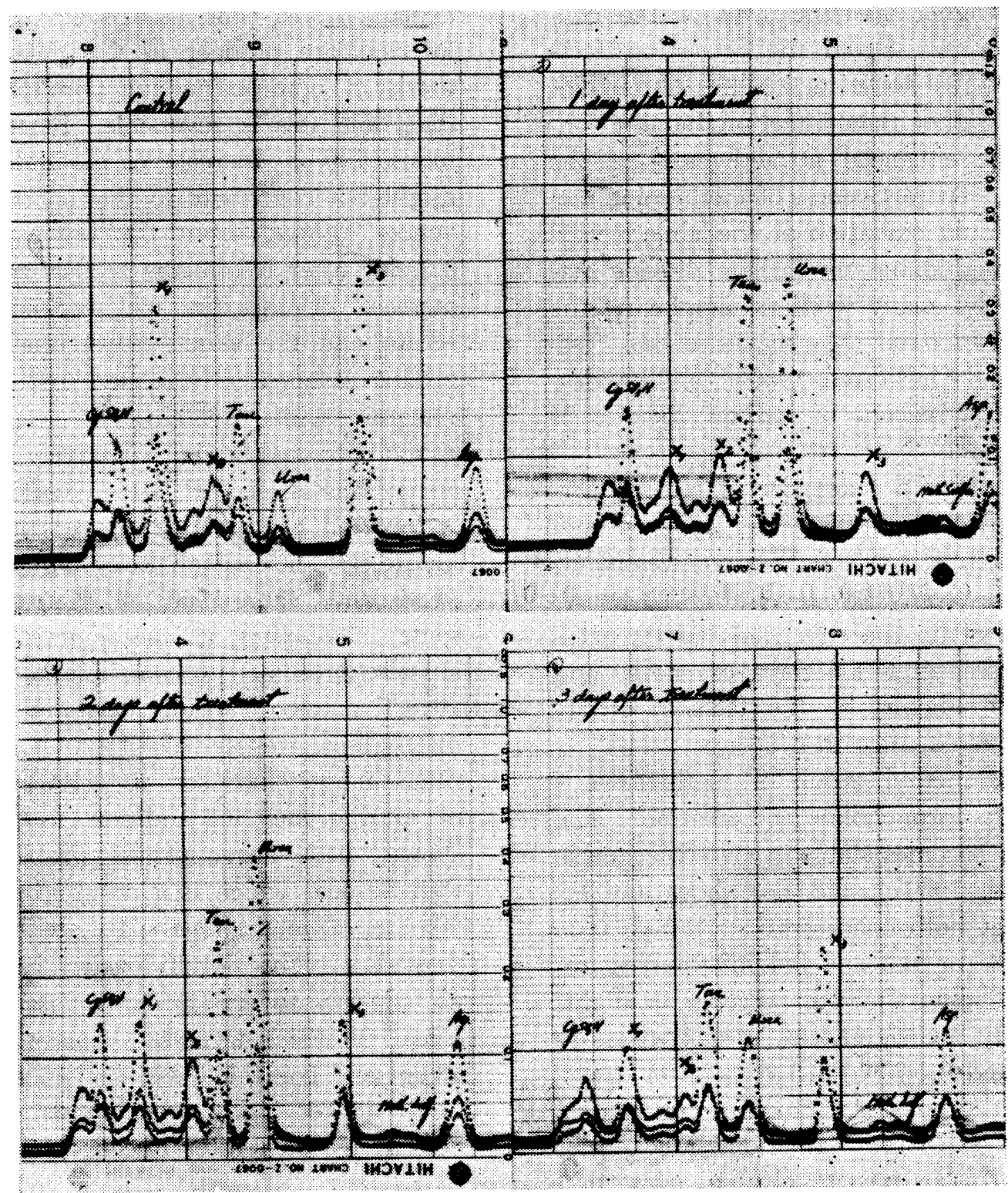

Fig. 1. Parts of chromatographies of free amino acids in the blood-serum of mice after intraperitoneal injection of $0.1 \mathrm{ml}$ of $0.5 \%$ methionine

Other A.A,\& Protein

Oxidation

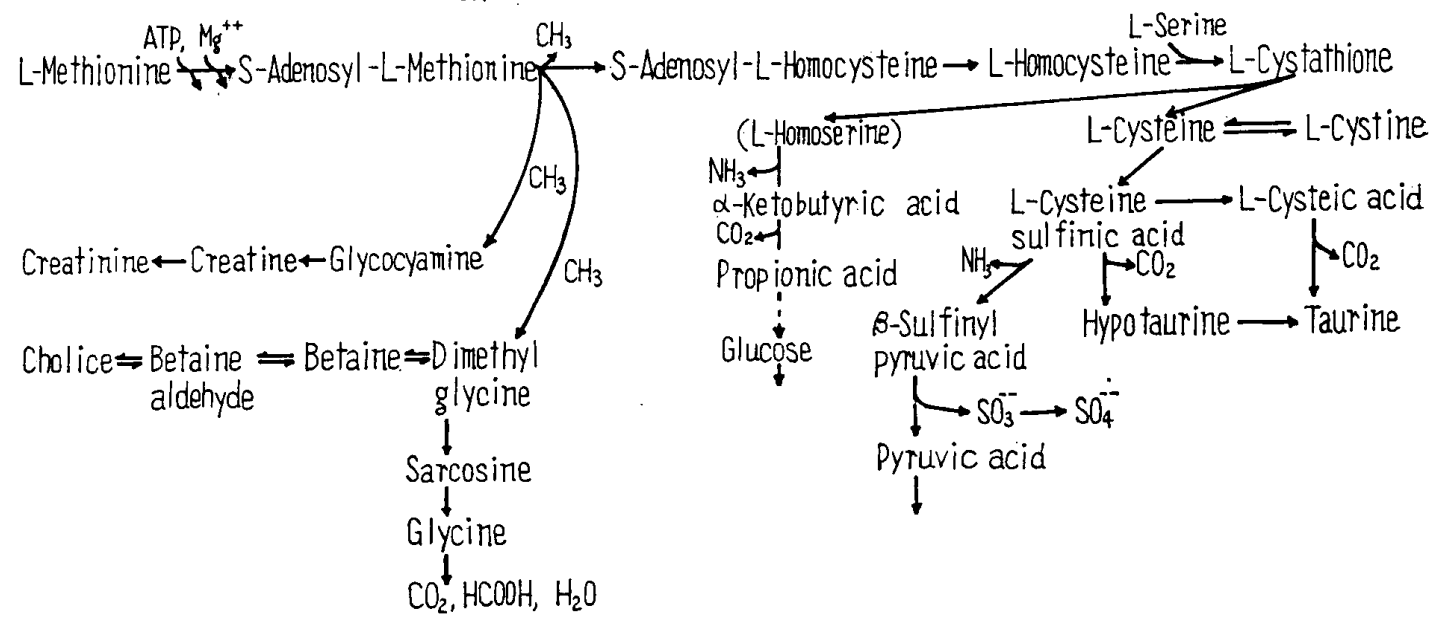

Fig. 2. Some metabolic pathways of L-Methionine 
was slightly higher than the 1.49 of the control blood serum. From the preceding facts it is concluded that some metabolites of methionine in vivo rather than intact methionine contribute to the enhanced attractiveness of the treated mice. Attractiveness of methionine metabolites : Rapid oxidation of the labile methyl moiety of methionine to carbon dioxide has been shown by many workers, employing the $\mathrm{C}^{14}$-labelled compound (Mackenzie, et al., 1949 and $1950 \mathrm{a}$, and Mackenzie, $1950 \mathrm{~b}$ ), and besides, the high attractiveness of carbon dioxide is well documented.

Hewever, since a sharp rise of labelled carbon dioxide from expiration was demonstrated to occur within a few hours after treatment, which fell to a steady low level after 24 hours, it does not explain the enhanced attractiveness of treated mice after 1.5 days or more, and is rather contradictory to the facts of attractiveness of treated mice in 0.5 day.

The labile methyl group of methionine is also utilized to form choline and creatine. The latter, which becomes stable in vivo (Mackenzie and Vigneaud, $1950 \mathrm{c}$ ), did not show any attractiveness at both concentrations tested, 0.05 $\%$ and $0.5 \%$ or 0.3 and 3.4 micromoles, respectively. Choline showed, however, a slight, but statistically non-significant, attractiveness at both $0.1 \%$ and $0.5 \%$ in 1.5 days after treatment. Methyl groups of methionine and betaine contribute to sarcosine formation (Mackenzie, $1950 \mathrm{a}$ ), and this in turn to glycine. Injection of 0.7 micromole of glycine was expectedly effective on 0.5 day, one day earlier than the time when 5 times the molecular number of methionine exhibitted maximum attractiveness. However, no increase of glycine was shown in the blood serum of mice treated with methionine by chemical analysis (Table 3). Glycine metabolites rather than the intact form are also presumed to contribute to enhanced attractiveness. It should be cited here that glycine was determined to be attractive by wetting the body surface of mice in previous experiments (Ikeshoji, 1963). The conclusion that methionine causes enhanced attractiveness through its metabolic products via glycine is, however, made only after the determination of the active metabolites common to both compounds.

Increase of aspartic acid in the blood serum after treatment with methionine can not be explained yet, but this is known to be an intermediate product in the microbial biosynthesis of homoserine and therefore of methionine, and this is reversible (Furton and Simmons, 1960). Increase of glutamic acid, which might not contribute to the enhanced attractiveness judging from the highest content in 0.5 day after treatment, is also related to the increase of aspartic acid both in the blood serum and the skin. Substantial decrease of proline is apparently related to the increase of glutamic acid. Cysteine and cystine when injected with methionine effectively cancelled the attractiveness of the latter, and since cystine is reported to diminish conversion of methionine to cysteine through the cystathionine pathway (Frost and Mann, 1966, and Kato, et al., 1964), some metabolites of methionine via cysteine are also presumed to contribute to the enhanced attractiveness. Taurine, one of the methionine metabolites, was actually found to increase 2.5 times in the blood serum. However, injection of taurine and its addition to blood serum showed little attractiveness (Table 1 and 2). Pyruvic acid which is a desulfulized lower metabolite of methionine via cysteine was attractive also. The desulfulization has, therefore, no concern to the attractiveness of cysteine. Urea, of which increased content in the blood serum and coincided with enhanced attractiveness, showed a slight but consistent attractiveness in 1.5 days after injection.

\section{SUMMARY}

In the preceding experiments, methionine was found to enhance the attractiveness of mice for mosquito biting when an aqueous solution was inpregnated on the body surface. Further experimentation on this was conducted by injection of $0.1 \mathrm{ml}$. of $0.5 \%$ methionine into a mouse intraperitoneally. Since there was no significant increase of methionine in the blood serum of the treated mice, and since blocking the metabolic pathways of methionine by addition of ethionine cancelled the enhanced attractiveness, some metabolites rather than the intact methionine were suspected to be responsible for this effect. Following the metabolic pathways of methionine in vivo, various probable metabolites were tested, and glycine was found to enhance attractiveness significantly, and 
cysteine and pyruvic acid somewhat less. Other probable metabolic compounds, creatine, choline and cystine, and taurine and urea actually detected by chromatographic analysis of the blood serum did not contribute to increased attractiveness. Since the contents of glycine and cysteine did not increase significantly in the blood serum when treated mice exhibited the enhanced effect, further metabolic compounds of these are suspected to be responsible for this. The desulfulization process of cysteine to pyruvic acid could not be related to this effect.

\section{REFERENCES}

1) Farber, E., K. H., Shull, S. Villa-Trevino, B. Lombardi and M. Thomas (1964): Biochemical pathology of acute hepatic adenosine triphosphate deficiency. Nature, 203 (4940) : 34-40. - 2) Furton, J. S. and S. Simmons (1960) : General biochemistry. John Wiley and Sons, Inc., New York. - 3) Frost, ann B. and G. V. Mann (1966) : Effects of cystine deficiency and trypsin inhibitor on the metabolism of methionine. J. Nutr., 89(1): 49-54. - Gouch, H. K. and C. E. Schreck (1965) : An olfactometer for use in the study of mosquito attractants. J. econ. Ent., 58(2) : 589-590. - 5) Ikeshoji, T., T. Umino and T. Suzuki (1963): On attractiveness of some amino acids and their decomposed products for the mosquitos, Culex pipiens pallens. Jap., J. San. Zool., 14(3) : 152-156. --6) Kato, A., T. Matsugawa, M. Suda, H. Nakagawa and J. Ishizuka (1964): Control mechanism in the rat lever enzyme system converting L-methionine to L-cystine. J. Biochem., 55 : 401. -- 7) Mackenzie, C. G., J. P. Chandler, E. B. Keller, J. R. Rachele, N. Cross and V. duVigneaurd (1949): The oxidation and distribution of the methyl group administered as methionine. J. Biol. Chem., 180 : 99-111. - 8) Mackenzie, C. G., J. R. Rache, N. Cross, J. P. Chandler and V du Vigneaurd (1950a): A study of the rate of oxidation of the methyl group of dietary methionine. J. Biol. Chem., 183 : 617-626. -9) Mackenzie, C. G. $(1950 \mathrm{~b})$ : Formation of formaldehyde and formate in the biooxidation of the methyl group. J. Biol. Chem., 186 : 351-368. -10) Mackenzie, C. G. and V, duVigneaud (1950c): Biochemical stability of the methyl group of creatine and creatinine. J. Biol. Chem., 185 : 185-189. 11) Smith, R. C. and W. D. Salmon (1965): Formation of S-adenosyl ethionine by ethionine-treated rats. Arch. Biochem. Biophys., 11(1) : 191-196.

$$
\begin{gathered}
\text { 摘 要 } \\
\text { メチオニンおよびその代謝産物の処理による } \\
\text { マウスの蚊に対する吸血誘引性の増大 }
\end{gathered}
$$

各種アミノ酸をマウス体表にぬつて，蚊の吸血誘引性 を調ベた結果，メチオニンが最も誘引性を高める事は， すでに報告した。

本実験で更に， 3.4 ミクロモルのメチオニンをマウス 腹腔内に注射した所, 1.5 日後にその誘引性が最大に達 する事を発見した．所が，血清中には，著しいメチオニ ンの増加はみとめられず，又，エチオニンを同時に注射 して, メチオニンの代謝を阻止した所, 誘引性の増加が 相殺された所から，メチオニンその物でなく，その代謝 産物が関係している事がわかつた，更に，種々の代謝産 物を注射又は，血清に附加する事によつて調らべた結 果, グリシンが著しく誘引性を増加させ，システィン及 び更にその代謝産物であるピルビン酸が，ある程度有効 であつた。 しかし，血清中に，これらアミノ酸の増加が みとめられない事から，更にこれらの低分子代謝産物が 関連している事が予想された. アミノ酸の分析結果から 血清中のタウリン，尿素の含量が，よく誘引性の增大と 時間的によく一致していたがマウスの誘引性増大には殆 んど関係しなかった。 